\title{
Teachers' Perception of Principals' Instructional Leadership Practices in Nigeria
}

\author{
Hafsat Aliyu Bada ${ }^{1, *}$, Tengku Faekah Tengku Ariffin ${ }^{2}$, Hasniza Nordin $^{2}$ \\ ${ }^{1}$ Department of Schools and Colleges, Kwara State Teaching Service Commission Ilorin, Nigeria \\ ${ }^{2}$ School of Education and Modern Languages, Universiti Utara Malaysia, Malaysia
}

Received May 26, 2020; Revised August 15, 2020; Accepted August 25, 2020

\begin{abstract}
Cite This Paper in the following Citation Styles
(a): [1] Hafsat Aliyu Bada, Tengku Faekah Tengku Ariffin, Hasniza Nordin, "Teachers' Perception of Principals' Instructional Leadership Practices in Nigeria," Universal Journal of Educational Research, Vol. 8, No. 10, pp. 4459-4469, 2020. DOI: 10.13189/ujer.2020.081013.
\end{abstract}

(b): Bada, H. A., Tengku Ariffin, T. F., \& Nordin, H. (2020). Teachers' Perception of Principals' Instructional Leadership Practices in Nigeria. Universal Journal of Educational Research, 8(10), 4459-4469. DOI: 10.13189/ujer.2020.081013.

Copyright $\subseteq 2020$ by authors, all rights reserved. Authors agree that this article remains permanently open access under the terms of the Creative Commons Attribution License 4.0 International License

\begin{abstract}
This study investigates teachers' perception of their school leaders, in particular, principals' instructional leadership practices, and tests whether teachers' perception varies across gender. A version of the Hallinger and Murphy [35] Principal Instructional Management Rating Scale (PIMRS) was employed and administered to 389 secondary school teachers in the North-Central geopolitical zone of Nigeria. The descriptive statistics show that there is a reasonable level of engagement of Nigerian school principals with the three dimensions of PIMRS. Specifically, "defining school mission" was rated highest, while "developing a positive school learning climate" has the lowest rating. This means that teachers perceive defining school mission as the greatest instructional leadership behaviour of the principals. Similarly, there appears to be significant differences between male and female teachers' perceptions of principal's instructional leadership behaviour among the principals. This difference occurs for "Managing the instructional program". This study adds to the understanding of instructional leadership practices in Nigeria, which have been rarely explored.
\end{abstract}

Keywords Instructional Leadership, PIMRS, Teachers' Perception, Nigeria

\section{Introduction}

Globally, education is fundamental for effective national development and economic growth, and a nation cannot develop beyond the level of its educational advancement. For this reason, the effectiveness of the school environment is vital because the school environment is a reflection of the society, [27, 61, 72]. However, for schools to be effective, the central role of principals and the morale of teachers are vital in the school environment $[12,36]$. This is because the principal is the person in charge of managing the daily activities of the school, which include addressing issues confronting the teachers daily and making sure teachers focus more on students and instruction $[63,76]$.

Principals are policy implementers and educational goal achievers $[2,15]$. In fact, studies on school effectiveness have documented that school effectiveness can be predicted by teachers' perception of the principals' leadership. For instance, in most instances, student achievement is connected to how the principal motivates and encourages classroom teachers [42]. In the United States (US), principals' leadership is also the main factor that systematically contributes to year end increases in student learning. In fact, successful principals spend ample time and energy in the development of people, are supportive to teachers and students, and hint teachers on their classroom instruction as well as the resources and avenue to act on principal's comments [73]. Such principals also provide opportunities for teachers to attend professional development courses that can assist in discharging their duties. Thus, it can be resolved that in the school environment, the principals' leadership role is crucial.

Although prior studies have documented that there are various leadership styles (e.g., transformational leadership 
and situational leadership styles, among others), however, one leadership style that is highly needed in the school environment is the principal's instructional leadership style. This style enables teachers to provide quality instruction and improve students' academic performance [10, 32, 49]. In instructional leadership style, the principal is considered as the school manager, responsible for setting goals, curriculum examination, teachers' evaluation and collaboration to accomplish the school's mission [8].

Considering the significance of instructional leadership, understanding teachers' perception about the principals' instructional leadership is necessary, particularly in the Nigerian environment, where the efficiency of secondary education has raised doubt among stakeholders in the Nigerian education sector. For instance, there has been public outcry on the performance of secondary school students' in external assessments. The reports on students from the West African Examination Council (WAEC), the Joint Admissions and Matriculation Board (JAMB) and other examination bodies, have consistently revealed a yearly declining performance in many key subjects (e.g., Mathematics and English, among others). This unimpressive performance has been attributed to the failure of the school authorities, in particular, principals, to discharge their duties $[7,38,52]$. Similarly, the lackadaisical attitude of teachers to teaching and students engaging in examination malpractices, have been attributed to the school principals' failure to exhibit appropriate leadership behaviour [57]. Likewise, the recent case of an epidemic at the Queen's College, Lagos State, that claimed three lives, has raised critical questions on how effective Nigerian principals are $[19,49]$.

Moreover, a principal is considered as the chief executive officer (CEO) in the school, saddled with the responsibility of keeping the school environment healthy for students, staff and the public. He or she is responsible for effective learning culture in the school through the provision of expertise and monitoring curriculum development, teaching methods and evaluation as well as supervision of human and material resources $[1,54]$. In short, principals influence school and learning outcomes, including school leaving examination results and progression to higher education institutions [11]. Thus, the instructional leadership of the principals can be an important educational component that would lead to better student achievement and school effectiveness [25, 30]. Similarly, the effectiveness of teachers towards instruction is strongly influenced by the support of the principals [47, $54,74]$. Prior studies have demonstrated that principals' leadership can influence teachers' instructional leadership practices that in turn, contribute to student learning and overall school effectiveness [73]. Similarly, the perception of teachers of their school leaders can influence student achievement in schools. On this basis, this study investigates teachers' perception of the instructional leadership practices of their principals and whether gender influence teachers' perception of principals' instructional leadership. The research on teachers' perception of principals' instructional leadership has been rarely conducted in Nigeria. Similarly, the gender differences are considered because one of the reasons for the increase in the number of women recruited is to increase the teaching service conditions [49], and noticeable differences exist in the proportion of male to female teachers in the country's education sector [53]. A reflection of this is the higher percentage of females in our sample. In addition, female teachers are found to be good at articulating and reviewing [70]. Similarly, teachers' gender shapes communication between teachers and students, with female teachers known to be better communicators [16]. Thus, female teachers may perceive the instructional role of principals differently compared to their male counterparts. In line with this notion, this research conducted a survey analysis of 389 secondary school teachers in the North-Central geopolitical zone of Nigeria and the descriptive statistics of the survey show that teachers perceive principals' instructional leadership practices in Nigeria more in terms of defining the school mission, and less on developing a positive learning school climate. In addition, teachers perceive principals differently in managing instructional programs, with the female teachers rating the principals higher on this category. Therefore, it can be argued that differences occur in teachers' perception of principals' instructional leadership according to their gender.

The remaining sections of the paper are section 2, which provides discussions on the literature review, section 3 which provides details on the research method, section 4 which discusses the results and section 5 which concludes the paper.

\section{Literature Review}

\subsection{The Principal as Instructional Leader}

The school principals play fundamental role in providing leadership to the schools and the wider community. This is especially so in recent times where there is high demand for principals to be accountable to happenings in the school environment and to keep abreast with educational goals. An essential instrument to attain the educational goals by the school principal is through leadership practices, in particular, instructional leadership [11, 28, 31, 37, 49].

Instructional leadership is multifaceted and demanding [5]. It captures different leadership styles (e.g., top-down, autocratic, transactional and transformational leadership styles) that make leaders grounded in standards or practices that are fundamental in the selection and implementation of instructional materials and monitoring [24, 40]. The standard practices include assuring quality of instruction and teaching resources, modelling teaching practices and curriculum supervision $[35,55]$. Thus, the vigorous role of 
principals as instructional leaders can improve the standard of schools. On this note, $[62,75]$ refer to principal as an individual that the instructional personnel look up to for instructional leadership.

Moreover, instructional leaders play a central role in influencing student learning [19]. Principals, as instructional leaders, are deeply engaged in the process of teaching and learning. This makes them the primary ingredient of instructional leadership in effective schools $[40,65]$. Thus, effective changes in classrooms can be regarded as the manifestation of principals' instructional leadership [17].

Andrews and Soder [3] mentioned four main domains the principal's actions as an effective instructional leader can be noticeable. These include principals being considered as instructional resource providers, communicators, resource providers and the ability to maintain visibility in the school. Likewise, [66] observed that effective principals would provide the needed resources required (e.g., knowledge and skills in curriculum and instructional matters) to attain academic school's goals. This is because they are skilled communicators and visionary leaders committed towards improvement of student achievement. For this reason, they ensure excellent instruction and the interactions between teachers and students are germane. Indeed, teachers assumed that their interaction with principal help to improve instructional practices. In another vein, [39] revealed that effective principals carry stakeholders of the school along in identifying, establishing and supervising the shared mission of the school. For instance, when principals are considered as instructional leaders, they help via continuous professional learning, particularly, on best practices that can improve teaching [45].

Another comprehensive study by [58] on the effects of leadership types on student achievement, demonstrates that instructional leadership consists of five dimensions. These include the participation of principal in the learning, development and promotion of teachers; initiation of goals and expectations; planning, coordination, and evaluation of teaching and curriculum; strategic resourcing; and maintaining a well-designed and supportive environment. All these suggest that instructional leadership consists of curriculum knowledge and a constituent of quality instruction [71], which entails planning, evaluation, coordination, and improvement of teaching [57]. By implication, principals' are expected to be consistent with the school's vision, organize resources to accomplish certain goals, informally drop into classrooms, prioritize staff development, ensure people do the right thing and reinforce these activities $[66,75]$.

\subsection{Principals' Instructional Leadership Influence on Teachers}

Having skilled teachers that keep students engaged is not enough for school effectiveness; the leaders must be supportive of the efforts of the teachers. Similarly, teachers' effect on school change is dependent on actions and beliefs of school principals [67]. Principals' leadership has a strong impact on educational reforms and student achievements [31,59] on teachers to achieve the goals [67] and objectives of the school, where teaching and learning are crucial [54]. The principals' leadership position in the school system is vital and their roles are complex, as it encompasses many duties and responsibilities, such as building community relationship, creating school culture, enhancing instructions, resolving managerial issues, managing crises and ensuring utmost discipline in the school environment. Among all, one major role is to be an instructional leader that will ensure that teachers are exposed to professional development in order to improve their teaching $[20,69]$. Teachers also prefer principals to be present (attending workshops and staff development programs) and active in all school programmes and activities, including teaching [56]. The principals' support of teachers is to create a school climate through effective leadership practices [62].

Principals, as instructional leaders influence teachers through inspirational support, encouraging and motivating, and creating an environment of collaboration and trust [23, $26,43]$. They are also required to provide needed mentoring on curriculum development and pedagogy, and motivate students to analyse teachers' strengths and weaknesses [64]. In fact, purposeful and focused instructional leadership encourages collaboration, provides support for instruction and promotes professional development and growth of teaching strategies [22]. When a collaborative working environment is created, it provides an avenue for teachers to grow in skills and development, which in turn, creates lifelong learners and enhances student achievement [30].

Similarly, the ability of the principal to create an instructionally-centred environment can influence teachers' instruction. That is an environment where clear school goals are communicated [68]. Through focused instructional leadership practices, principals have the possibility to influence teachers' professional learning, and this can positively affect student achievement outcomes because teachers are a major factor impacting student achievement [48], and they play a pivotal in the classroom environment, which in turn, affects student learning $[14,48$, $60]$.

Teachers are also helpful to students in making conceptual connections [77]. They are facilitators and motivators in teaching and learning; most student behaviour and performance are attributed to them because they tend to imitate them $[51,52]$. As such, instructionally-focused principals can affect successful teaching in the classroom and student conduct [22]. A study by [5], on teachers' perception of principals' instructional leadership in the US, has revealed that teachers find that effective principals are principals who provide insights and talk to them on what can make them grow, or promote reflection. Such leaders, who listen to the 
teachers, are very helpful and have positive influences on student learning. The authors further indicated that principals who have positive influence on student learning are those who interact with teachers, provide suggestions, give feedback and promote professional development by emphasizing teaching and learning, supporting collaboration and coaching. [21] study of the perception of 105 teachers of primary school on principals' instructional leadership in Alor Gajah, Malaysia, reveals a moderate level of perception of instructional leadership functions in defining school mission and managing instructional leadership. However, there is low level of perception of instructional leadership functions related to promoting a positive climate. In addition, the authors reported no significant differences of gender in teachers' perception of instructional leadership.

Another study by [40] on teachers' perception of principals' instructional leadership practices shows that their teachers perceive that their principals seek to promote an instructional atmosphere. These principals are knowledgeable about curriculum. They promote teachers' professional development and student learning. All these suggest that instructional leadership practices have direct influence on teachers and classroom instructions. Indeed, engaging teachers in instructional interaction and meaningful supervision tend to result in good pedagogy and teaching. Therefore, investigating principals' instructional practices, which are perceived as instrumental to teachers' effectiveness or enhancing instruction is crucial. On this note, this study investigates the instructional leadership practices of principals as perceived by teachers in Nigerian secondary schools. This study uses Nigeria as a case study because [1] claimed that Nigerian principals are not involved in the instructional supervision process. Therefore, there is need to empirically investigate whether or not Nigerian principals engage with instructional leadership and the aspects they practice.

\subsection{Hallinger Model of Instructional Leadership (PIMRS)}

The most widely acceptable model for measuring and defining instructional leadership as suggested by prior scholars like [44] is the [35] PIMRS. The PIMRS is considered as a valid and reliable instrument to determine principal's instructional leadership practices. The PIMRS consists of three main dimensions of leadership practices, namely, defining the school mission; managing the instructional program; and promoting a positive school learning climate. The three dimensions are further classified into 10 functional roles of instructional leadership (see Figure 1). For instance, the first dimension, which is defining the school's mission, has two functions: "framing the school goals and communicating the school goals". This indicates that instructional leaders should have a clear vision of what the school plans to accomplish. However, this requires the involvement of staff in developing the broader goals of accountability and instructional improvement. The goals relate to the ability of the principal to engage staff in order to make sure that the school has a clear mission, which is the students' academic performance. By so doing, the principal has the responsibility of communicating and articulating the vision of learning and building support because the attainment of the school's mission cannot be achieved solely by the principal, but by communicating with other stakeholders in the school community [33].

The role of the principal in supervising and evaluating instructions, coordinating the curriculum and the monitoring of students' progress is captured in the second dimension, which is "Managing the instructional program". In this dimension, the principal has the sole responsibility of ensuring that teachers provide good quality teaching and learning in the school in order to achieve educational goals. For instance, an aspect of managing the instructional program is to coordinating the curriculum. The essence is to ensure that students receive appropriate instruction [35]. Therefore, it is the responsibility of the principal to delegate authority to the subordinates through instructional supervision.

The last dimension is "Developing a positive school learning climate". This dimension has more functions than the two earlier mentioned dimensions of instructional leadership. The dimension provides details on the principals' functions that are inclusive of transformational leadership. This includes protecting instructional time, providing incentives for teachers and learners, promoting professional development and maintaining high visibility. Through these functions, principals play a crucial role in building positive school climate by providing motivational means and support for both the teachers and learners. The creation of culture that would foster and reward continuous improvement and learning is saddle with principals' responsibility. In short, all the 10 functions of principals are widely connected to teachers' professional growth and performance. In view of this, this study applies the PIMRS developed by [35] to determine teachers' perception of the principals' behaviour in Nigeria. 


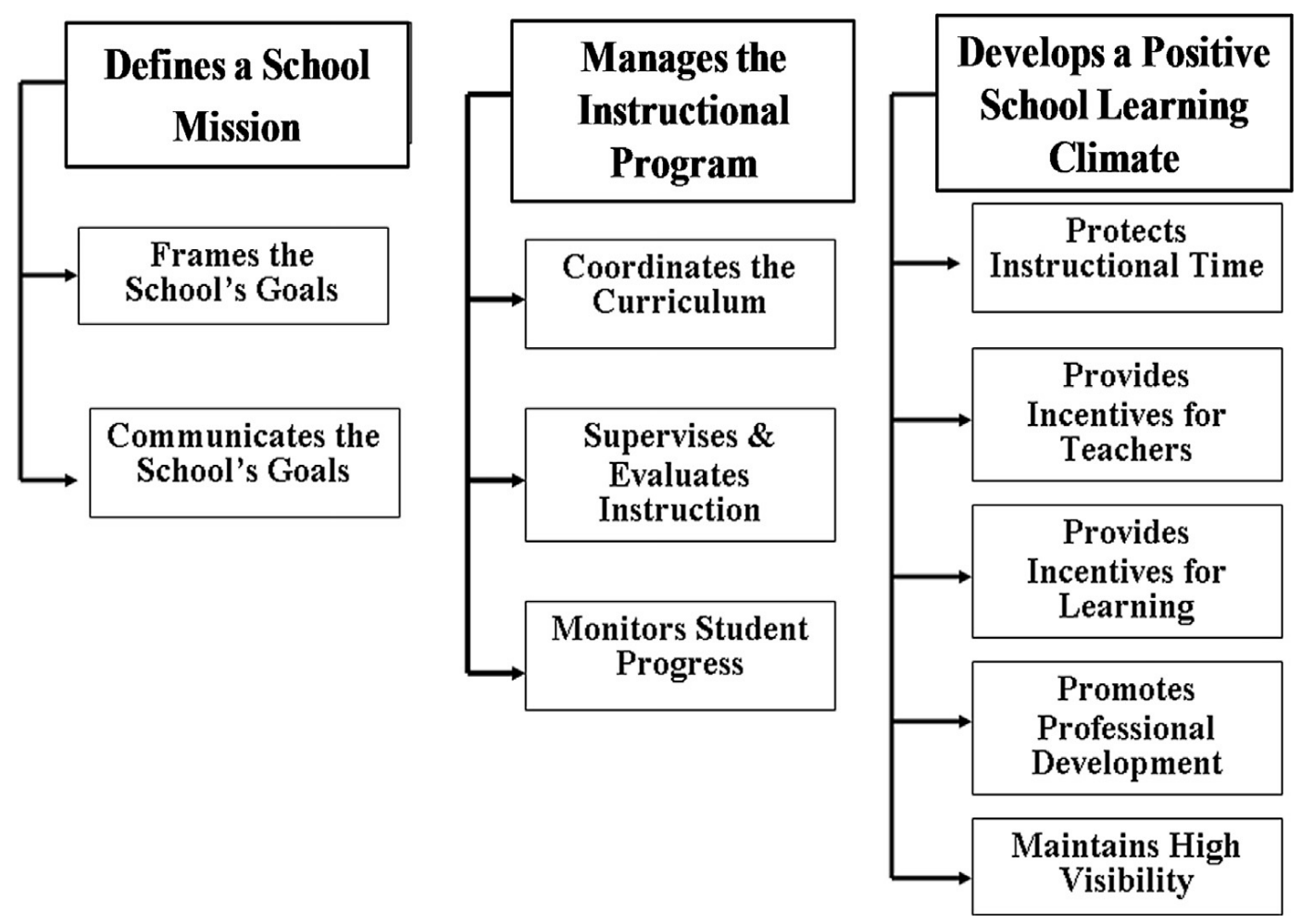

Figure 1. Principal Instructional Management Rating Scale (PIMRS) Framework by Hallinger and Murphy (1985)

\section{Research Method}

The quantitative research approach is employed to answer the study objectives. The objectives are answered through the descriptive statistics and the t-test of significance. The t-test of significance allowed the study to test the presence of any significant difference between teachers' gender and their perception of principal instructional leadership practices. In addition, the data were collected through a survey (primary data). The PIMRS questionnaire was administered to the respondents to find out the instructional leadership practices of secondary school principals in Nigeria.

\subsection{Population and Sample}

The school teachers of public secondary schools in the North Central Geopolitical zone in Nigeria form the population of the study. This is based on a convenient sample to administer the questionnaire to 18 public secondary schools in the region. A total of 420 questionnaires were administered to obtain information on teachers' perception of principals' instructional leadership using the PIMRS. According to the 420 questionnaires administered to teachers, the response rate is $86.4 \%(n=389$ respondents), comprising 158 male and $231 \mathrm{female}$ teachers.

\subsection{Instrumentation}

This study applied the 35-item version of the PIMRS teachers' form to investigate principals' instructional leadership practices in Nigerian secondary schools. The 35 items were arrived at based on a pilot survey and expert validation in the context of Nigeria. These items were administered to a group of school teachers in 18 public secondary schools across the states in the North Central region of Nigeria. The items in the questionnaire were based on the main dimensions of instructional leadership, which are defining the school mission, managing the instructional program and promoting a positive school climate. Examples of some of the items in the questionnaire relate to, "To what extent does your principal .....?; Use data on students' performance when developing the school's academic goals; Ensure that the school has achieved the school's curriculum objectives; and Encourage teachers to use instructional time to apply new skills or concepts. Each of these items was rated on a five-point Likert scale, ranging from 1 (Almost Never) to 5 (Almost Always).

\section{Results and Discussion}

The internal consistency reliability test, which is a procedure to estimate the reliability of scores using only one administration of the instrument, was measured through Cronbach's Alpha. The essence of this is to determine the degree to which the indicators that make up a scale are consistent [9]. Based on the internal consistency test, the coefficients of Cronbach's alpha are presented in Table 1 . The Table 1 results indicate that defining the school mission has a Cronbach's alpha value of 0.87 ; managing the instructional program is 0.84 
developing positive school learning climate is 0.85 . Therefore, the three dimensions of instructional leadership exceed the threshold of 0.70 , which is considered as adequate, meaning that all the items are internally consistent and reliable for the test $[13,50]$.

Table 1. PIMRS Dimension Internal Consistency Analysis

\begin{tabular}{|l|l|}
\hline VARIABLES & Cronbach's Alpha \\
\hline Defining the school mission & 0.868 \\
\hline Managing the instructional program & 0.838 \\
\hline Developing a positive school learning climate & 0.846 \\
\hline
\end{tabular}

Since the first aim of the study is to find out teachers' perception of principals' instructional leadership practices, a descriptive analysis of teachers' responses was conducted. According to the descriptive results displayed in Table 2, the overall mean score for the three dimensions of instructional leadership based on the perception of teachers is $(\mathrm{M}=3.65$ and $\mathrm{SD}=0.76)$. As for the individual dimension of instructional leadership, developing a positive school learning climate has the lowest mean score $(\mathrm{M}=3.62$ and $\mathrm{SD}=0.74)$. However, 'defining school mission' has the highest mean score $(\mathrm{M}=3.67$ and $\mathrm{SD}=0.80)$ and managing the instructional program has a mean score $(\mathrm{M}=3.65$ and $\mathrm{SD}=0.75)$. These results show that teachers have varied levels of perception of the role of principals as instructional leaders. In fact, there is clear indication that principals perform better in terms of defining school mission as compared to other dimensions of instructional leadership because its mean score is higher than the overall mean score. Likewise, the perception of teachers of their principals' role in managing the instructional program is perceived moderately because its mean score is the same as the overall mean score. In addition, the perception of teachers of the dimension related to developing a positive school learning climate clearly shows that more needs to be done in this regard, as the mean score is lower than the overall mean score. All these provide insights into the varying degrees of perception of instructional leadership practices of teachers in Nigerian secondary schools.

The results documented herein add to extant studies on instructional leadership practices among the principals. For instance, [3] study of 299 school teachers in Oman, reported that there is a moderate level of commitment by principals in 'defining the school mission' and 'developing positive school learning climate'. Similarly, [76] reported that teachers' perception of instructional leadership practices of principals is more on "creating a school mission" and "developing positive school learning climate", while their perception of principals in 'managing the instructional program' is low. [21] study on teachers' perception of principal's instructional leadership in Malaysia, shows that the principals' roles in defining school mission and managing the instructional program are better perceived by the teachers, whereas in terms of promoting a positive school learning climate, principals are perceived as below average. The study of [36] in Malaysia reveals that principals do not see promotion as a positive school learning climate as their key responsibilities are as instructional leaders. In contrast, [34] documented that Thai principals focus more on "defining the school mission" and "promoting a positive school learning climate" than "managing the instructional program".

In addition to the investigation on teachers' perception of principals' instructional leadership, this study examined whether gender plays a significant role in teachers' perception of instructional leadership practices of principals. Table 3 presents the results of the independent sample test on the significant influence of gender.

Table 2. Mean Score of PIMRS Dimensions

\begin{tabular}{|c|c|c|c|c|}
\hline Statistics & Overall & $\begin{array}{c}\text { Defining the school } \\
\text { mission }\end{array}$ & $\begin{array}{c}\text { Managing the instructional } \\
\text { program }\end{array}$ & $\begin{array}{c}\text { Developing a positive school } \\
\text { learning climate }\end{array}$ \\
\hline Mean & 3.65 & 3.67 & 3.65 & 3.62 \\
\hline Std. Deviation & 0.76 & 0.80 & 0.75 & 0.74 \\
\hline
\end{tabular}

Table 3. Independent Samples t-Test

\begin{tabular}{|c|c|c|c|c|c|c|c|}
\hline \multirow{2}{*}{ Variables } & \multicolumn{2}{|c|}{ Female } & \multicolumn{2}{c|}{ Male } & \multicolumn{2}{c|}{} \\
\cline { 2 - 8 } & Mean & Std. Deviation & Mean & $\begin{array}{c}\text { Std. } \\
\text { Deviation }\end{array}$ & t-value & Df & Sig. \\
\hline Defining the school mission & 3.71 & 0.73 & 3.60 & 0.89 & 1.365 & 387 & 0.173 \\
\hline $\begin{array}{c}\text { Managing the instructional } \\
\text { program }\end{array}$ & 3.72 & 0.70 & 3.56 & 0.82 & 2.127 & 387 & $0.034^{* *}$ \\
\hline $\begin{array}{c}\text { Developing a positive school } \\
\text { learning climate }\end{array}$ & 3.67 & 0.69 & 3.55 & 0.80 & 1.546 & 387 & 0.123 \\
\hline $\mathrm{N}$ & 231 & & 158 & & & & \\
\hline
\end{tabular}

Note**significant at 0.05 
From the results presented in Table 3, the mean score of female teachers for each of the dimensions of instructional leadership is more than that of the male. However, when it comes to the statistical tests of significance, the significant difference is only found in the PIMRS dimension related to "managing instructional program". This implies that teachers view their principals differently in this aspect of instructional leadership behaviour. The significant differences in managing instructional leadership are more visible for coordinating the curriculum and monitoring student progress. Notwithstanding the significant differences, male and female teachers rate their principal low when it comes to "points out specific strength and/or weakness in teachers' institutional practices in post-observation feedback (e.g., conference and evaluation)". In addition to the independent sample test, a regression analysis was conducted using a one-time measure of principals' instructional leadership. The result shows that gender is significantly and positively associated with principals' instructional leadership. These results are consistent with [29] findings which report that gender has a "small but significant effect" in shaping perception of instructional leadership from teachers' perception.
Similarly, [41] reported a gender difference in the teachers' perception of principals' instructional leadership practices. They find that female teachers feel empowered when working in schools with a female principal. In contrast, male teachers find themselves less powerful in this circumstance.

Besides the comparison of teachers' perception of principals' instructional leadership by gender, a comparison was also made on whether teachers' years of experience could affect their perception of the three dimensions of principals' instructional leadership. A look at Table 4 shows that teachers with more years of experience perceive the principals' instructional leadership more than those teachers with lesser years of experience do. However, the four multivariate statistics computed using the MANOVA presented in Table 5 shows that it is only the Roy's largest root values which indicate differences in the mean value of the three dimensions of principals' instructional leadership. Therefore, we cannot simply conclude that the teachers' teaching experience has significant impact on the teachers' rating of principal's instructional leadership.

Table 4. Mean values of teachers' perception of principal Instructional leadership by teachers' experience

\begin{tabular}{|c|c|c|c|c|c|c|c|}
\hline & & \multicolumn{6}{|c|}{ Mean values } \\
\hline $\begin{array}{c}\text { Years of } \\
\text { experiences }\end{array}$ & Observation & \multicolumn{2}{|c|}{$\begin{array}{l}\text { Defining the school } \\
\text { mission }\end{array}$} & \multicolumn{2}{|c|}{$\begin{array}{l}\text { Managing the instructional } \\
\text { Program }\end{array}$} & \multicolumn{2}{|c|}{$\begin{array}{l}\text { Developing a positive school } \\
\text { climate }\end{array}$} \\
\hline $0-5$ & 96 & \multicolumn{2}{|c|}{3.72} & \multicolumn{2}{|c|}{3.65} & \multicolumn{2}{|c|}{3.60} \\
\hline $6-10$ & 124 & \multicolumn{2}{|c|}{3.60} & \multicolumn{2}{|c|}{3.66} & \multicolumn{2}{|c|}{3.61} \\
\hline $11-15$ & 107 & \multicolumn{2}{|c|}{3.70} & \multicolumn{2}{|c|}{3.65} & \multicolumn{2}{|c|}{3.67} \\
\hline $16-20$ & 28 & \multicolumn{2}{|c|}{3.51} & \multicolumn{2}{|c|}{3.36} & \multicolumn{2}{|c|}{3.40} \\
\hline $21-25$ & 12 & \multicolumn{2}{|c|}{3.93} & \multicolumn{2}{|c|}{3.68} & \multicolumn{2}{|c|}{3.64} \\
\hline $26-30$ & 16 & \multicolumn{2}{|c|}{3.71} & \multicolumn{2}{|c|}{3.90} & \multicolumn{2}{|c|}{3.76} \\
\hline 30 and above & 6 & \multicolumn{2}{|c|}{3.96} & \multicolumn{2}{|c|}{4.24} & \multicolumn{2}{|c|}{3.92} \\
\hline Total & 389 & \multicolumn{2}{|c|}{3.67} & \multicolumn{2}{|c|}{3.65} & \multicolumn{2}{|c|}{3.62} \\
\hline \multicolumn{8}{|c|}{ Independent Samples t-Test } \\
\hline \multirow{2}{*}{\multicolumn{2}{|c|}{ Variables }} & \multicolumn{2}{|c|}{$0-5$ years } & \multicolumn{2}{|c|}{ 6-10years } & \multicolumn{2}{|c|}{$11+$ years } \\
\hline & & Mean & p-value(a) & Mean & p-value(b) & Mean & p-value(c) \\
\hline \multicolumn{2}{|c|}{ Defining the school mission } & 3.72 & 0.28 & 3.60 & 0.30 & 3.69 & 0.84 \\
\hline \multicolumn{2}{|c|}{$\begin{array}{l}\text { Managing the instructional } \\
\text { Program } \\
\end{array}$} & 3.66 & 0.98 & 3.66 & 0.94 & 3.65 & 0.96 \\
\hline $\begin{array}{r}\text { Developing a p } \\
\text { clim }\end{array}$ & e school & 3.60 & 0.91 & 3.61 & 0.74 & 3.64 & 0.66 \\
\hline Observa & & & & & & & \\
\hline
\end{tabular}

$\mathrm{a}$ is the difference between mean values of 0-5years and 6-10years

$\mathrm{b}$ is the difference between mean values of 6-10years and 11years and above

$\mathrm{c}$ is the difference between mean values of $0-5 y e a r s$ and 11 years and above

Table 5. Multivariate analysis of variance and covariance (MANOVA)

\begin{tabular}{|c|c|c|c|cc|c|c|}
\hline Variable & & Statistics & $\mathrm{df}$ & $\mathrm{F}(\mathrm{df1}, \quad \mathrm{df2})$ & $\mathrm{F}$ & Prob $>\mathrm{F}$ \\
\hline Years of experience & Wilks' lambda & 0.93 & 7 & 21.0 & 1088.8 & 1.30 & $0.16 \mathrm{a}$ \\
\hline & Pillai's trace & 0.07 & & 21.0 & 1143.0 & 1.30 & $0.16 \mathrm{a}$ \\
\hline & Lawley-Hotelling trace & 0.07 & & 21.0 & 1133.0 & 1.30 & $0.16 \mathrm{a}$ \\
\hline & Roy's largest root & 0.04 & & 7.0 & 381.0 & 2.31 & $0.03 \mathrm{u}$ \\
\hline
\end{tabular}

$\mathrm{a}=$ approximate, $\mathrm{u}=$ upper bound on $\mathrm{F}$ 


\section{Conclusions}

The purpose of instructional leadership deals with enhancing teaching and providing detailed supervision that would help teachers to develop and improve their professional knowledge, skills, and abilities. In congruency with the targeted purpose of instructional leadership, this study investigated teachers' perception of their principals' instructional leadership in Nigeria, and whether there are gender differences in teachers' perception. A version of the PIMRS developed by Hallinger was administered to secondary school teachers in the North Central geo-political zone in Nigeria. The findings reveal a moderate level of teachers' perception of their principals' roles in instructional leadership practices. Specifically, out of the three dimensions of instructional leadership, the results show that "defining the school missions" has the highest rating. This means that teachers perceive the principal to have performed excellently in defining the school mission to them. However, the instructional leadership dimension which relates to "developing positive school learning climate "was rated lowest. This indicates that the principals are poorly rated when it comes to developing a positive learning climate. The poor rating of the principals in this aspect is more on the inability of the principals to provide incentives for teachers and promoting professional development. For instance, most of the teachers rated their school principals low on questions related to "acknowledgement of teachers' outstanding performance by writing (letters of recommendations) to their personal files" and "setting aside time to discuss in-service programs during staff meetings". These evidences suggest that principals need to improve on providing incentives for teachers and promoting their professional development. This is because when teachers' performance is acknowledged and professional development encouraged by the principals, it would improve teachers' effectiveness, thereby enhancing students' learning.

Additional results on the significant differences between male and female teachers' perception of instructional leadership, show that a significant difference exists in the dimension related to "managing the instructional time". The implication of this result is that male and female teachers perceive the principals' instructional role in managing instructional time differently. These results suggest that there is need for more training of principals on the dimension related to "develop positive learning climate and manage instructional programmes' in their schools for the attainment of educational goals and objectives. This study is useful to school leaders in highlighting the practices teachers considered valuable and those that need more attention. The study is also helpful to policymakers in developing instructional leadership for Nigerian principals.

\section{REFERENCES}

[1] Abdulrasheed, O., \& Bello, A. S. (2015). Challenges to secondary school principalse leadership in northern region of Nigeria. British Journal of Education, 3(3), 1-5.

[2] Alghanabousi, N. S. (2010). Can you try this model? Introducing an instructional leadership model for teacher performance evaluation. OIDA International Journal of Sustainable Development, 1(2), 61-76.

[3] Al-Mahdy, Y. F. H., Emam, M. M., \& Hallinger, P. (2018). Assessing the contribution of principal instructional leadership and collective teacher efficacy to teacher commitment in Oman. Teaching and Teacher Education: An International Journal of Research and Studies, 69(1), 191-201. DOI:10.1016/j.tate.2017.10.007

[4] Andrews, R. L., \& Soder, R. (1987). Principal leadership and student achievement. Educational leadership, 44(6), 9-11.

[5] Blase, J., \& Blase, J. (1999). Principals' instructional leadership and teacher development: Teachers' perspectives. Educational Administration Quarterly, 35(3), 349-378.

[6] Blase, J., \& Blase, J. (2002). Teachers' perceptions of principals' instructional leadership and implications. Leadership and Policy in Schools, 1(3), 256-264.

[7] Bolanle, A. O. (2013). Principals' Leadership Skills and School Effectiveness: The Case of South Western Nigeria. World Journal of Education, 3(5), 26-33. DOI:105430/wje3n5p26

[8] Bolden, R., Gosling, J., Marturano, A., \& Dennison, P. (2003). A review of leadership theory and competency frameworks. Centre for leadership studies, University of Exeter.

[9] Bryman, A. (2012). Social research methods (4th ed.). Oxford, United Kingdom: Oxford University Press.

[10] Bush, T., Bell, L., \& Middlewood, D. (2019). Principles of Educational Leadership \& Management: SAGE Publications Limited.

[11] Bush, T., \& Glover, D. (2016). School leadership and management in South Africa: Findings from a systematic literature review. International Journal of Educational Management, 30(2), 211-231. DOI:10.1108/IJEM-07-2014-0101

[12] Day, C., Gu, Q., \& Sammons, P. (2016). The impact of leadership on student outcomes: How successful school leaders use transformational and instructional strategies to make a difference. Educational Administration Quarterly, 52(2), 221-258. DOI:10.1177\%2F0013161X15616863

[13] DeVellis, R. F. (2003). Scale development: Theory and Application (2nd ed. Vol. 26). Thousand Oaks, CA: SAGE Publications, Inc.

[14] Ding, C., \& Sherman, H. (2006). Teaching effectiveness and student achievement: Examining the relationship. Educational Research Quarterly, 29(4), 40-51.

[15] Enueme, C. P., \& Egwunyenga, E. J. (2008). Principals' instructional leadership roles and effect on teachers' job performance: A case study of secondary schools in Asaba 
Metropolis, Delta State, Nigeria. Journal of Social Sciences, 16(1), 13-17. DOI:10.1080/09718923.2008.118 92596

[16] Etim, J. S. (2019). Investigating Relationship between Teachers Gender and Experience of Teaching Types of Writing in Nigerian Secondary Schools. International Journal of English Language and Literature Studies, 8(3), 87-98.

[17] Fink, E., \& Resnick, L. B. (2001). Developing principals as instructional leaders. Phi Delta Kappan, 82(8), 598-610.

[18] Folarin, S. (2019 September 30,). Again, infection breaks out in Queen's College, hundreds of pupils affected. . The Punch.

[19] Fullan, M. (2002). Principals as leaders in a culture of change. Educational leadership, 59(8), 16-21.

[20] Gale, J. J., \& Bishop, P. A. (2014). The work of effective middle grades principals: Responsiveness and relationship. RMLE Online, 37(9), 1-23.

[21] Ghavifeekr, S., Radwan, O., \& Velarde, J. M. (2019). Teachers' Perceptions of Principals' Instructional Leadership Roles and Practices. Malaysian Journal of Education (0126-6020), 44(2).

[22] Glanz, J., Shulman, V., \& Sullivan, S. (2007). Impact of Instructional Supervision on Student Achievement: Can We Make the Connection? Online Submission.

[23] Gurley, D. K., Anast-May, L., O'Neal, M., \& Dozier, R. (2016). Principal Instructional Leadership Behaviors: Teacher vs. Self-Perceptions. International Journal of Educational Leadership Preparation, 11(1), n1.

[24] Hallinger, P. (2003). Leading educational change: Reflections on the practice of instructional and transformational leadership. Cambridge Journal of Education, 33(3), 329-352.

[25] Hallinger, P. (2005). Instructional leadership and the school principal: A passing fancy that refuses to fade away. Leadership and Policy in Schools, 4(3), 221-239. DOI: 10.1080/15700760500244793

[26] Hallinger, P. (2018a). Bringing context out of the shadows of leadership. Educational Management Administration \& Leadership, 46(1), 5-24.

[27] Hallinger, P. (2018b). Principal Instructional Leadership: From Prescription to Theory to Practice. The Wiley Handbook of Teaching and Learning, 505-528. DOI: $10.1177 \% 2 \mathrm{~F} 0013161 \mathrm{X} 10383412$.

[28] Hallinger, P., Adams, D., Harris, A., \& Jones, M. S. (2018). Review of conceptual models and methodologies in research on principal instructional leadership in Malaysia. Journal of Educational Administration, 56(1), 104-126 DOI: $10.1108 /$ JEA-03-2017-0025

[29] Hallinger, P., Dongyu, L., \& Wang, W. C. (2016). Gender differences in instructional leadership: A meta-analytic review of studies using the principal instructional management rating scale. Educational Administration Quarterly, 52(4), 567-601.

DOI:10.1177/0013161X16638430
[30] Hallinger, P., \& Heck, R. H. (1996). The principal's role in school effectiveness: An assessment of methodological progress, 1980-1995 International handbook of educational leadership and administration (pp. 723-783): Springer.

[31] Hallinger, P., \& Heck, R. H. (1998). Exploring the principal's contribution to school effectiveness: 1980 1995. School effectiveness and school improvement, 9(2), 157-191. DOI: 10.1080/0924345980090203

[32] Hallinger, P., \& Heck, R. H. (2011). Exploring the journey of school improvement: Classifying and analyzing patterns of change in school improvement processes and learning outcomes. School effectiveness and school improvement, 22(1), 1-27. DOI: $10.1108 / 09578231111116699$

[33] Hallinger, P., \& Lee, M. (2013). Exploring principal capacity to lead reform of teaching and learning quality in Thailand. International journal of educational development, 33(4), 305-315.

[34] Hallinger, P., \& Lee, M. (2014). Mapping instructional leadership in Thailand: Has education reform impacted principal practice? Educational Management Administration \& Leadership, 42(1), 6-29.

[35] Hallinger, P., \& Murphy, J. (1985). Assessing the instructional management behavior of principals. The Elementary School Journal, 86(2), 217-247. DOI: $10.1086 / 461445$

[36] Harris, A., Jones, M., Adams, D., \& Cheah, K. (2019). Instructional leadership in Malaysia: a review of the contemporary literature. School Leadership \& Management, 39(1), 95.

DOI:10.1080/13632434.2018.1453794

[37] Jarvis, A. (2018). 10 Instructional or Distributed Leadership? Comparing Two Approaches to the Improvement of Learning in Schools. Mastering Theories of Educational Leadership and Management.

[38] Josiah, O., \& Oluwatoyin, K. (2017). Teacher quality as determinant of students' academic performance in secondary schools in Edo South Senatorial District of Nigeria. British Journal of Education, 5(13), 19-30.

[39] Lambert, L. (2002). A framework for shared leadership. Educational leadership, 59(8), 37-40.

[40] Leech, D., Pate, J. L., Gibson, N. M., Green, R., \& Smith, R. (2009). Teacher Perceptions of the Instructional Leadership Practices of Principals. School Leadership Review, 4(2), 6.

[41] Lee, V. E., Smith, J. B., \& Cioci, M. (1993). Teachers and principals: Gender-related perceptions of leadership and power in secondary schools. Educational Evaluation and Policy Analysis, 15(2), 153-180. doi./10.3102/01623737015002153

[42] Leithwood, K., Harris, A., \& Hopkins, D. (2008). Seven strong claims about successful school leadership. School leadership and management, 28(1), 27-42. DOI:10.1080/13632430701800060

[43] Leithwood, K., Harris, A., \& Hopkins, D. (2008). Seven strong claims about successful school leadership. School 
leadership and management, 28(1), 27-42.

[44] Leithwood, K., Jantzi, D., \& Steinbach, R. (1999). Changing leadership for changing times: McGraw-Hill Education (UK).

[45] Leithwood, K., \& Riehl, C. (2003). What do we already know about successful school leadership. AERA division a task force on developing research in educational leadership, 1-60.

[46] Maktoub, M., M.. (2019, November 21.). On The Queen's College 'Eyelashes' Debacle. . The Daily Trust.

[47] Mangin, M. M. (2007). Facilitating elementary principals' support for instructional teacher leadership. Educational Administration Quarterly, 43(3), 319-357. DOI: 10.1177\%2F0013161X07299438

[48] Marzano, R. J. (2007). Designing a comprehensive approach to classroom assessment. Ahead of the curve: The power of assessment to transform teaching and learning, 103-125.

[49] May, H., \& Supovitz, J. A. (2011). The scope of principal efforts to improve instruction. Educational Administration Quarterly, 47(2), 332-352. DOI: $10.1177 / 0013161 X 10383411$

[50] Nunnally, J. C. (1978). Psychometric theory (2nd ed.). New York, USA: McGraw-Hill Education.

[51] Nwagwu, C. (1994). Women in Nigeria's Teaching Profession: the challenges ahead. The Vocational Aspect of Education, 46(2), 167-180.

[52] Ojo, O. E., \& Olajide, A. A. D. (2014). The Nigerian Secondary School Graduate and National Development: A Case of Re-Education of Teachers,4(6),21-24. DIO: 10.1.1.1020.8259\&rep=rep1\&type $=$ pdf

[53] Okoro, C. C., Ekanem, I. E., \& Udoh, N. A. (2012). Teacher gender and the academic performance of children in primary schools in Uyo Metropolis, Akwa Ibom State, Nigeria. Journal of Educational and social Research, 2(1), 267-267.

[54] Olaleye, F. (2008). Principal's leadership behaviour and school learning culture in secondary schools in Ekiti-State Nigeria. Pakistan Journal of Social Sciences, 5(9), 856-860. DOI:pjssci.2008.856.860

[55] Portin, B., Schneider, P., DeArmond, M., \& Gundlach, L. (2003). Making sense of leading schools: A study of the school principalship.

[56] Ringler, M. C., O'Neal, D., Rawls, J., \& Cumiskey, S. (2013). The Role of School Leaders in Teacher Leadership Development. Rural Educator, 35(1), n1.

[57] Robinson, V. M. (2010). From instructional leadership to leadership capabilities: Empirical findings and methodological challenges. Leadership and Policy in Schools, 9(1), 1-26.

[58] Robinson, V. M., Lloyd, C. A., \& Rowe, K. J. (2008). The impact of leadership on student outcomes: An analysis of the differential effects of leadership types. Educational Administration Quarterly, 44(5), 635-674.

[59] Ronfeldt, M., Farmer, S. O., McQueen, K., \& Grissom, J.
A. (2015). Teacher collaboration in instructional teams and student achievement. American Educational Research Journal, 52(3), 475-514.

[60] Rowan, B., Correnti, R., \& Miller, R. J. (2002). What large-scale, survey research tells us about teacher effects on student achievement: Insights from the prospectus study of elementary schools.

[61] Sagala, S., Lubis, W., \& Sagala, G. H. (2019). Canonical correlation between principal leadership and school capacity. International Journal of Management in Education, 13(3), 256-280. DOI: 10.1504/IJMIE.2019.100413

[62] Sanchez, J. E., Paul, J. M., \& Thornton, B. W. (2020). Relationships among teachers' perceptions of principal leadership and teachers' perceptions of school climate in the high school setting. International Journal of Leadership in Education, 1-21.

[63] Shaked, H., \& Benoliel, P. S. (2019). Instructional boundary management: The complementarity of instructional leadership and boundary management. Educational Management Administration \& Leadership. DOI:10.1177\%2F1741143219846905

[64] Sim, Q. C. (2011). Instructional leadership among principals of secondary schools in Malaysia. Educational Research, 2(12), 2141-2161.

[65] Smith, J. B., Maehr, M. L., \& Midgley, C. (1992). Relationship between personal and contextual characteristics and principals' administrative behaviors. The Journal of Educational Research, 86(2), 111-118.

[66] Smith, W. F., \& Andrews, R. L. (1989). Instructional leadership: How principals make a difference: ERIC.

[67] Stein, K. C., Macaluso, M., \& Stanulis, R. N. (2016). The interplay between principal leadership and teacher leader efficacy. Journal of School Leadership, 26(6), 1002-1032.

[68] Supovitz, J., Sirinides, P., \& May, H. (2010). How principals and peers influence teaching and learning. Educational Administration Quarterly, 46(1), 31-56.

[69] Supovitz, J. A., \& Poglinco, S. M. (2001). Instructional leadership in a standards-based reform.

[70] Unterhalter, E., ,Ezegwu, C., Shercliff, E., Heslop, J., \& North, A. (2015) Training teachers and gender equality in Nigeria: Reflections on measurement and policy. Paper presented at CIES annual conference, Washington DC, March 2015 . https://www.britishcouncil.org.ng/sites/default/files/traini ng_teachers_and_gender_equality_in_nigeria.pdf

[71] Wahlstrom, K. L., \& Louis, K. S. (2008). How teachers experience principal leadership: The roles of professional community, trust, efficacy, and shared responsibility. Educational Administration Quarterly, 44(4), 458-495.

[72] Wan, S. W.-Y., Law, E. H.-F., \& Chan, K. K. (2018). Teachers' perception of distributed leadership in Hong Kong primary schools. School Leadership \& Management, 38(1), 102-141. DOI:10.1080/13632434.2017.1371689

[73] Ward, C. J. (2013). Why Leadership Matters: One School's Journey to Success. Educational Leadership and Administration: Teaching and Program Development, 24, 
$62-74$

[74] Weiner, J. M. (2011). Finding common ground: Teacher leaders and principals speak out about teacher leadership. Journal of School Leadership, 21(1), 7-41. DOI: $10.1177 \% 2 \mathrm{~F} 105268461102100102$

[75] Whitaker, B. (1997). Instructional leadership and principal visibility. The clearing house: A journal of educational strategies, issues and ideas, 70(3), 155-156.
[76] Yasser, F., \& Amal, R. (2015). Teachers' perceptions of principals' instructional leadership in Omani schools. American Journal of Educational Research, 3(12), 1504-1510. DOI:10.12691/education-3-12-4

[77] Ye, Y., \& Singh, K. (2017). The effect of working condition on math teacher effectiveness: value-added scores and student satisfaction in teaching. Educational Research for Policy and Practice, 16(3), 283-295. 